Coastal Dynamics 2009

Paper No.

\title{
MODELLING TRANSITIONS BETWEEN BARRED BEACH STATES ON A STRAIGHT COAST
}

\author{
Darrell Strauss ${ }^{1}$ and Rodger Tomlinson ${ }^{1}$
}

\begin{abstract}
The utility of numerical models of beach morphodynamics is constrained by our ability to establish that the theoretical dynamics match reality. The inherent difficulty in collecting suitable validation data for spatial and temporal bathymetric models of beach evolution has resulted in relatively few studies which perform empirical validation of nearshore morphological models. The present study addresses the validity of morphological modelling of an exposed beach by qualitatively comparing the evolution of a numerically modelled beach state transition with data observed using remote imaging. The application of the numerical model was broadly validated, in that, when forced with parameterised wave conditions, the morphological development is consistent with that observed via optical sensing.
\end{abstract}

Key words: hydrodynamics, sediment transport, morphodynamics, beach states, numerical modelling.

\section{Introduction}

The identification of hazardous beach conditions is aided by an understanding of the complex processes capable of altering the morphology of barred beaches. Rips in particular represent a significant threat to beach users. Rips were identified as being directly responsible for 10 national drowning deaths in 20052006 and playing a role in over 90\% of surf rescues on Australian beaches. The 2006 National Surf Safety Report from Surf Life Saving Australia (SLSA) states that of the 98\% of Australians who intend to visit the beach each summer, more than $70 \%$ do not know how to recognise a rip current by looking at the water (Surf Life Saving Australia 2006).

Transitions between individually classified beach states are readily observed in sequential time averaged video images. Recognising the existence of distinct antecedent beach morphologies and analysing wave data co-incident with observed morphological change highlights conditions which can trigger a transition between beach states. Several intermediate beach state transitions and the wave conditions surrounding the change of state are analysed in this manner to produce conceptual models of beach state transitions. A regional wave model is constructed to simulate the propagation of waves derived from the Wavewatch III deepwater global model (Tolman, 2002) to a near shore hydrodynamic and sediment transport model, Delft 3D (http://delftsoftware.wldelft.nl/). The SWAN (Booij et. al 1999) wave model in Delft3D was calibrated with directional wave buoy data and beach state transitions were simulated using the deepwater wave model hindcast parameters.

The Gold Coast wave climate is typically dominated by south to southeast swells which originate from the eastward passage of low pressure systems in the Southern Ocean or from Tasman Sea lows between May and November. High energy northeast to east swells originating from cyclones in the Coral Sea are typically confined to the period from December to May (Strauss et. al., 2009). Tropical cyclones are regarded as having the highest potential for extreme wave heights and destruction however intense storms, known as East coast lows, are responsible for more of the high wave events. East Coast Lows can develop rapidly in close proximity to the coast resulting in energetic swells and destructive winds. While they may occur anytime, they are generally more prevalent between March and July (Allen and Callaghan, 2000).

The tide is predominantly semi-diurnal and micro-tidal with a tidal amplitude which ranges from 0.2 to $2.1 \mathrm{~m}$ and a mean range of $1 \mathrm{~m}$. The sediment is fine sand with $\mathrm{d}_{50}=200 \mu \mathrm{m}$.

${ }^{1}$ GCCM, Griffith University, Gold Coast, 4222, Australia. D.Strauss@griffith.edu.au 
Coastal Dynamics 2009

Paper No.

The northern end of the coast is more exposed to swells of southerly origin while Point Danger at the southern end induces an incomplete refraction of waves in the surf zone. As a consequence there are often high rates of littoral drift in this area. The resultant net northward sediment transport rate has been estimated at $500,000 \mathrm{~m}^{3} / \mathrm{yr}$. The net transport rate is comprised of approximately $650,000 \mathrm{~m}^{3} / \mathrm{yr} \mathrm{of}$ northward transport and 150,000 $\mathrm{m}^{3} / \mathrm{yr}$ of southward transport (Turner, 2006).

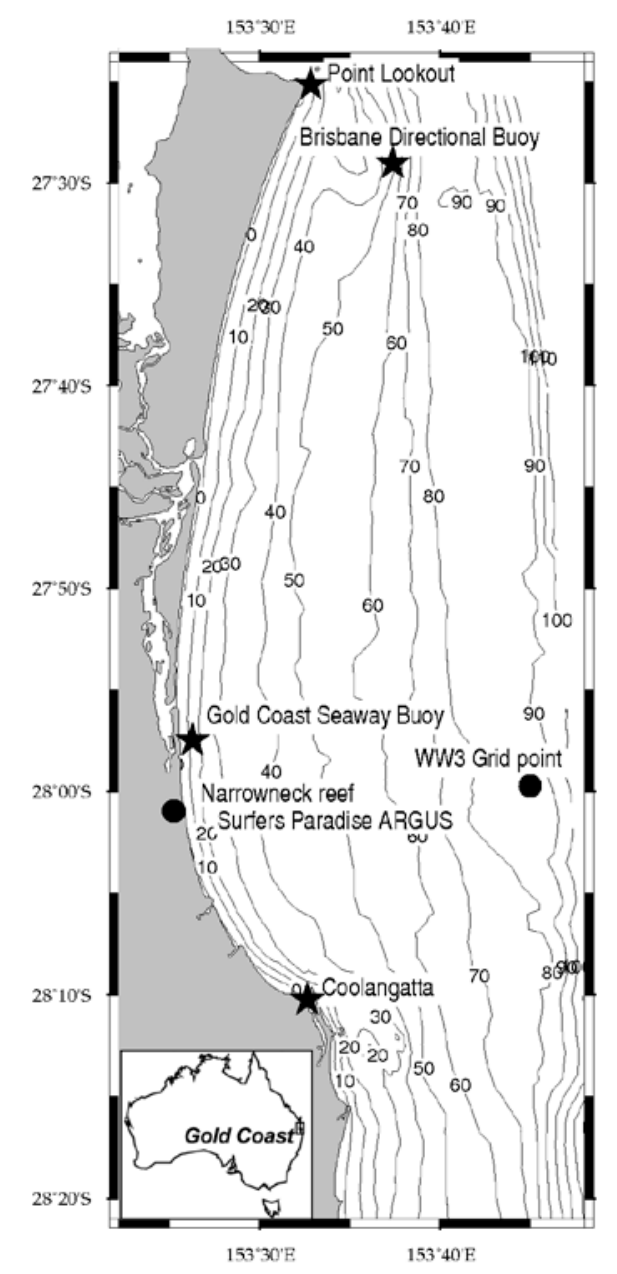

Figure 1. Gold Coast location map

\section{Monitoring Beach State Transitions}

The widely used beach state model of Wright and Short (1984) provides a means of classifying distinct surf zone morphologies. Beaches which exhibit primarily intermediate beach states are the most likely to present a hazard to beach users in the form of rips or strong longshore currents. The long, straight coastline of the northern Gold Coast, Australia is subject to significant net northward littoral transport and exposed to a highly variable wave climate. The beach regularly exhibits the higher energy intermediate beach states of longshore bar and trough, rhythmic bar and beach and transverse bar and rip as described by the Wright and Short classification. The presence of a curvilinear bar structure, indicative of rip currents, poses the greatest threat to the safety of water users. The highest rescue risk according to the analysis of lifeguard statistics was associated with a surf zone consisting of an attached bar, single curvilinear trough and high intensity outer surf zone (Walsh et. al. 1999). 
Paper No.

Gold Coast City Council (GCCC) implemented video based monitoring with an Argus coastal imaging system in July 1999 (Turner et. al. 2000). The installation aimed to provide continuous, quantitative information and long-term monitoring of coastal change. Of particular interest was the regional response to the construction of a submerged artificial reef at Narrowneck Beach. Wave breaking on the reef is clearly visible on the left part of figures 2 and 3. An additional benefit is that the daily timex images provide a quick visual identification of the beach morphology and occurrences of transitions between the intermediate beach states. The following section describes two separate beach state transitions and the associated wave conditions. Both examples concern the transition from a linear bar to transverse bar and rip morphologies.

\subsection{Beach state transition - January 11th to January 16th 2005}

Figure 2 is a timex image taken on January 11th 2005 at the Northern Gold Coast coastal imaging site. The sub-tidal bar structure consists of a long-shore uniform outer bar to the south (right) of the influence of the submerged artificial reef at Narrowneck. Over the course of the next five days, until the 16th January 2005, there was a marked increase in the curvilinearity of wave dissipation on the outer bar. The transformation of the bar morphology resulted in well-defined rip channels and transverse bar structures.

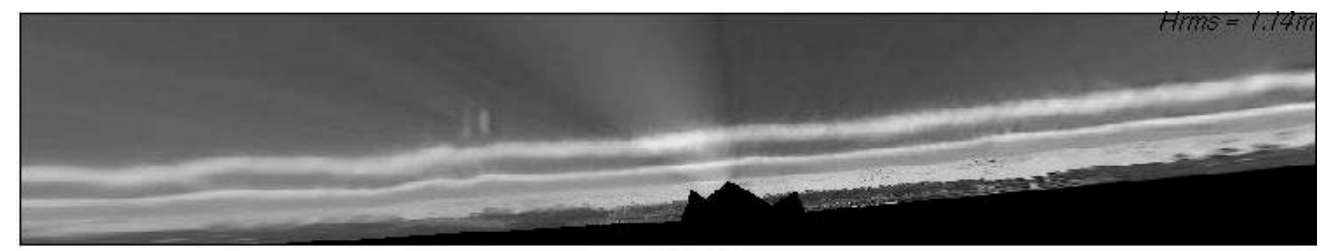

2005-01-11

Figure 2. Argus image of Linear Bar and Trough morphology (GCCC, WRL UNSW).

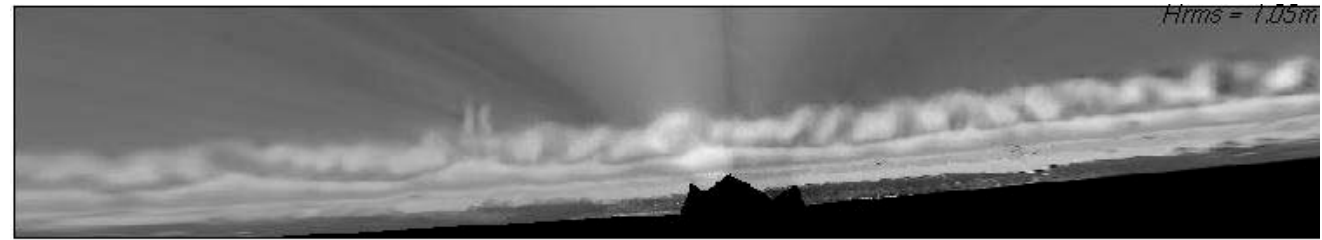

2005-01-16

Figure 3. Argus image of Transverse Bar and Rip morphology (GCCC, WRL UNSW).

The wave climate for the 4 days prior to the beach state transition, January 8th until January 12 th, is displayed in figures 4, 5 and 6 . This period was characterised by a low waves with a significant wave height of 1-1.5m and a 6-8 second peak period. The waves were incident from the south-southeast on the 9th January and progressively shifted more easterly from the 10th to 12th January. The beach state remained in the long-shore bar and trough state (Figure 2) until the 12th January, 2005.

On the 13th of January there was an increase in wave energy with a maximum significant wave height of $2.5 \mathrm{~m}$ and a maximum peak wave period of 11 seconds on the 15th of January. Wave direction was consistently incident from the east at approximately 85 degrees. It appears that the surf zone bar morphology responded to the decay in longshore current and subsequent increase in wave driven rip cell circulation. The timex image in Figure 3 clearly shows increased curvilinearity of the wave dissipation resulting from alongshore non-uniform wave breaking. By the 16th of January the significant wave height decreased to $1.5 \mathrm{~m}$. The transverse bar and rip morphology remained until another high energy event caused a 'reset' to longshore bar and trough morphology on the 25th January, 2005. 


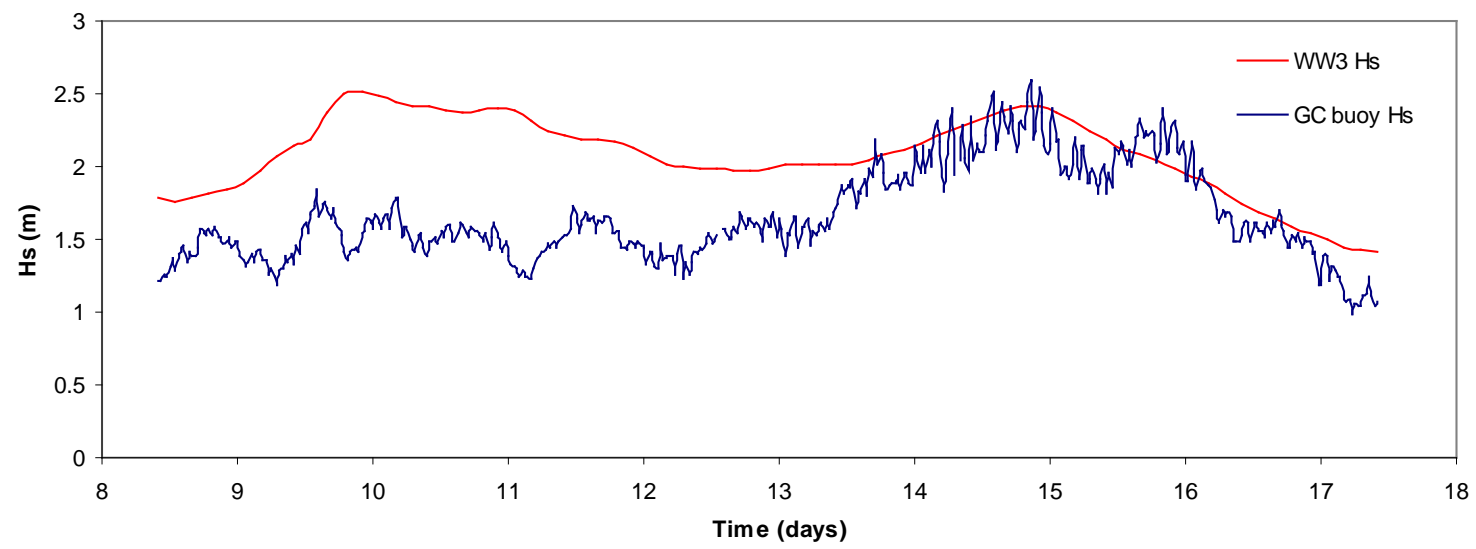

Figure 4. Significant wave height, WW3 and Gold Coast wave buoy

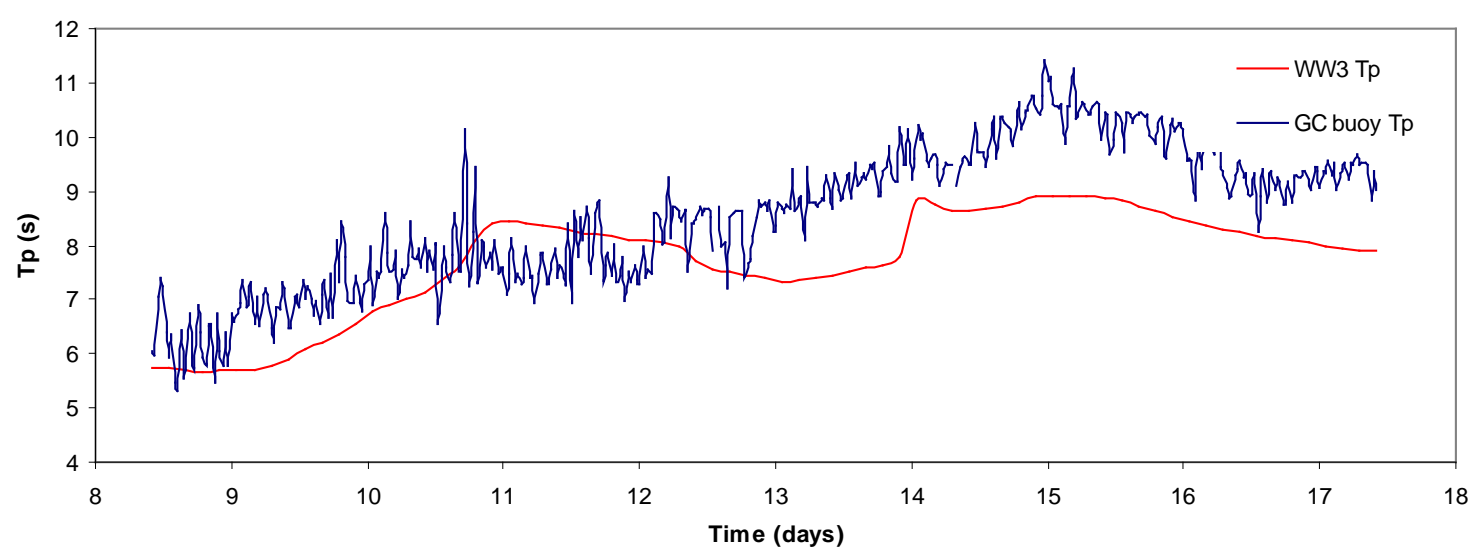

Figure 5. Peak wave period, WW3 and Gold Coast wave buoy

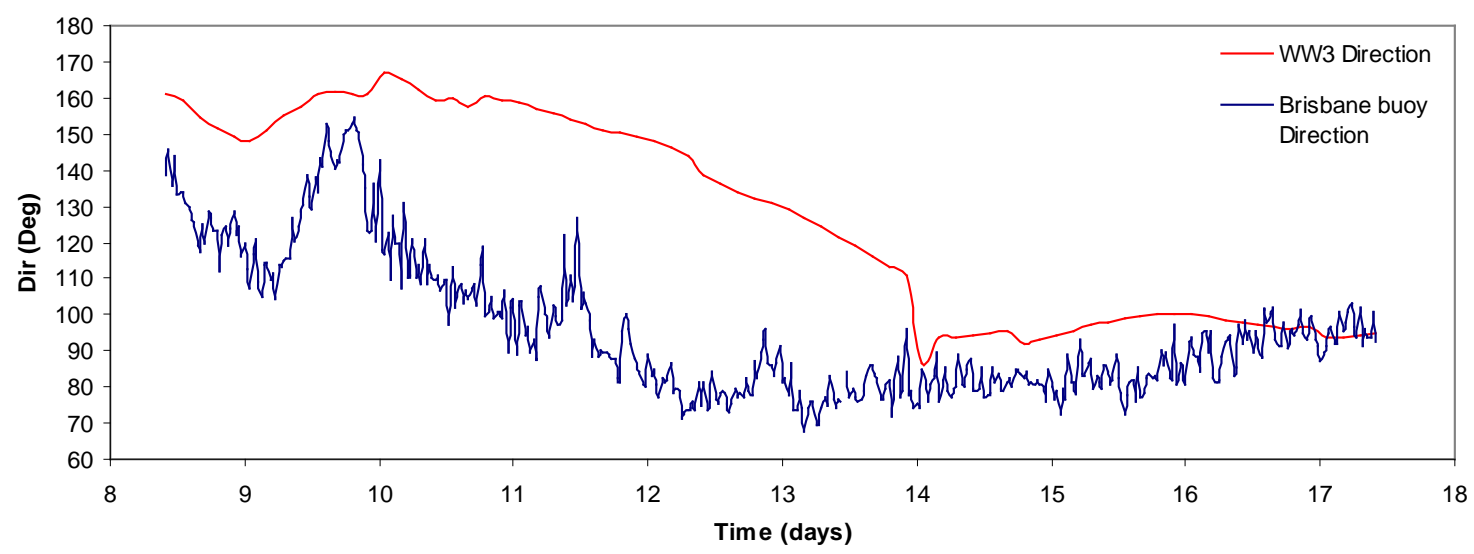

Figure 6. Wave Direction, WW3 and Brisbane wave buoy 
Coastal Dynamics 2009

Paper No.

\subsection{Beach State Transition - February 17th to February 28th, 2007}

Throughout January 2007 the bar morphology of the Northern Gold Coast beaches exhibited strongly curvilinear, alongshore non-uniform features. Low southeast to east swell prevailed before a rise in SE swell to $2 \mathrm{~m}$ (Figure 10) with periods of 11-13 seconds (Figure 11) on the 14th February. Linearity began to appear on the outer bar between the 12th and 13th February 2007. The outer bar was observed to straighten significantly in contrast to the curvilinearity of the previous six weeks. By the 17th February a continuous long shore trough separated the inner and outer bars (Figure 7).

Despite the appearance of the longshore trough and straightening of the outer bar there remained alongshore non-uniform features in the inner bar. The inner bar at this time could be considered to be shore attached. It is assumed that shoreline irregularities existed from the prolonged period of non-uniformity. These inter-tidal features may have encouraged the persistence of alongshore non-uniform circulation near shore.

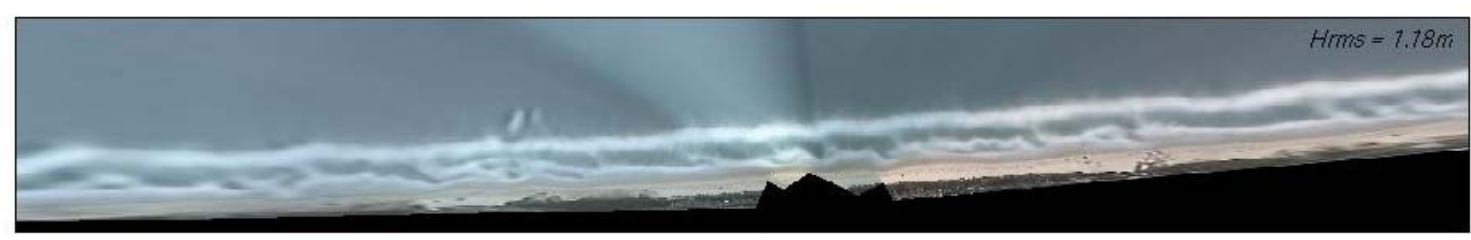

17/02/2007 11:15

Figure 7. Linear outer bar morphology, February 17th 2007

Between the 18th and 19th of February significant curvilinearity returned to the outer bar (Figure 8). The longshore trough and outer (or currently single) bar was repeatedly interrupted by closely spaced rip channels. Wave heights persisted at around $1.5-2 \mathrm{~m}$ and wave direction shifted from the southeast to the east until 28th February (Figure 12). The observed series of rips and transverse bar structures remained and demonstrated gradual shoreward migration until February 28th (Figure 9).

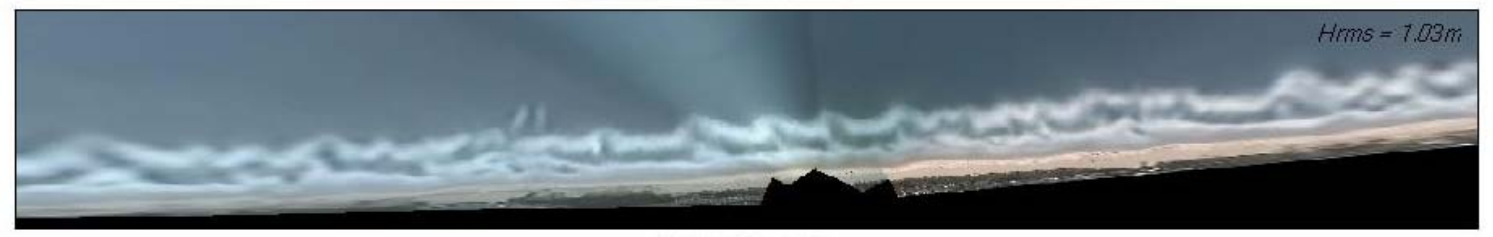

$19 / 02 / 2007$ 12:15

Figure 8. Alongshore non-uniform bar and rip morphology, February 19th 2007

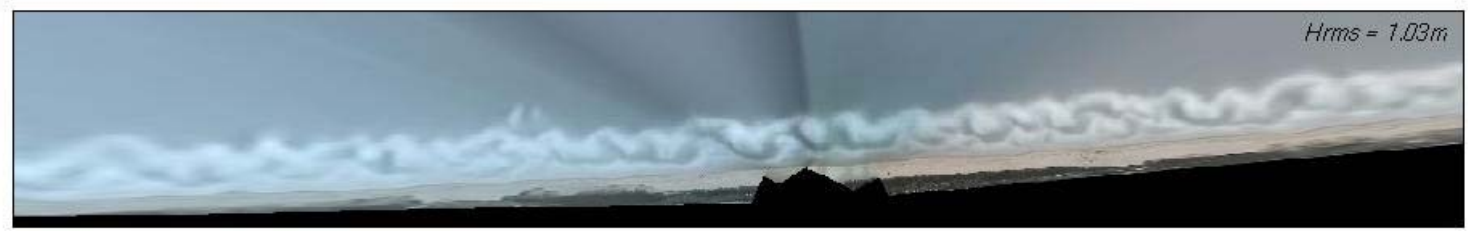

$28 / 02 / 200716: 15$

Figure 9. Transverse bar and rip morphology, February 28th 2007 


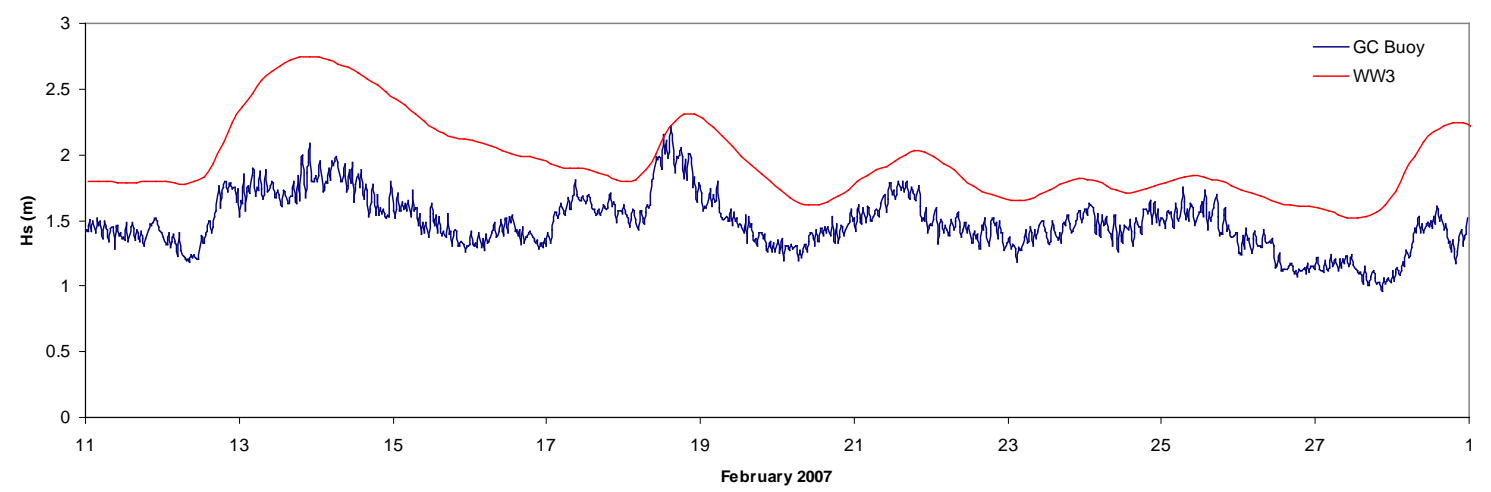

Figure 10. Significant wave height, WW3 and Gold Coast wave buoy

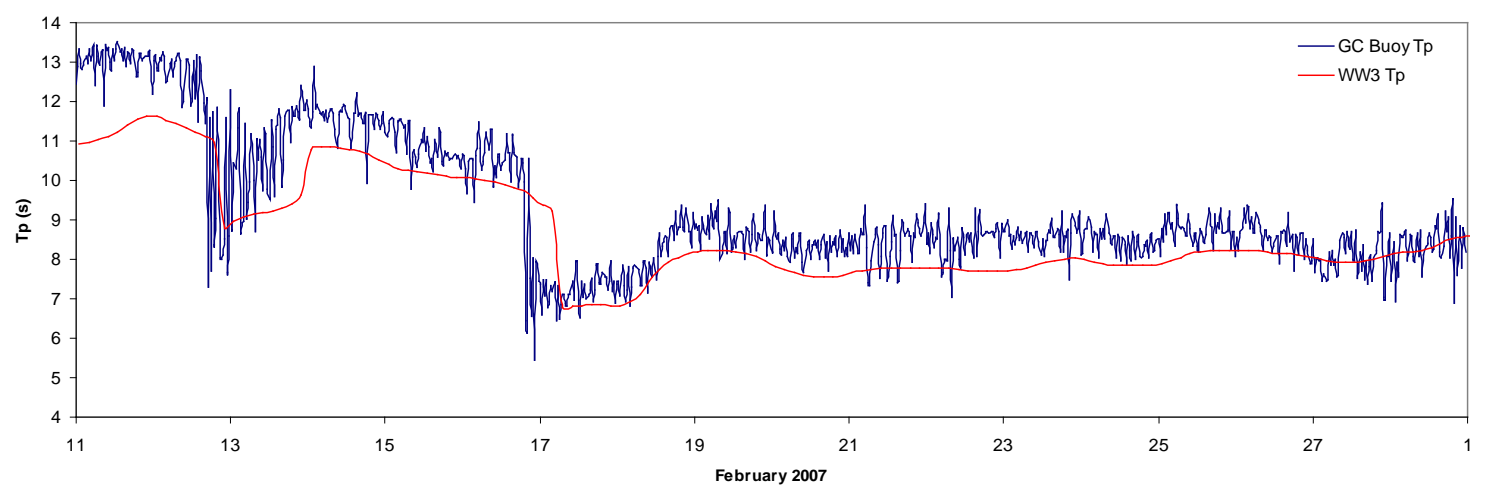

Figure 11. Peak wave period, WW3 and Gold Coast wave buoy

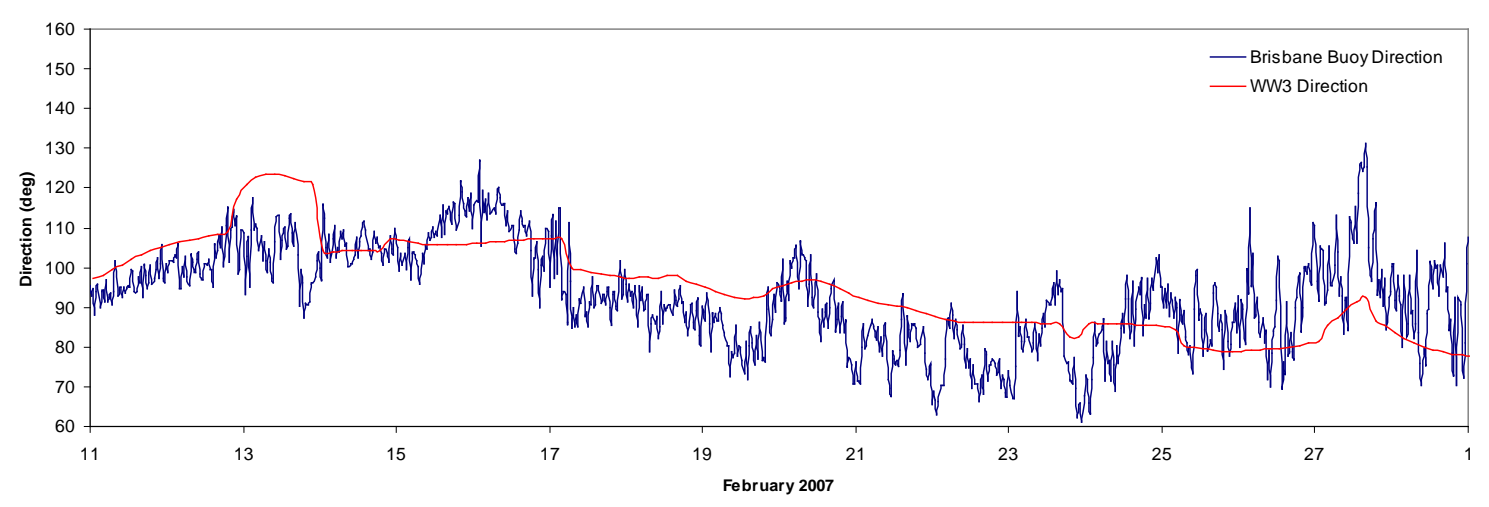

Figure 12. Wave direction, WW3 and Brisbane wave buoy

Previous studies have noted that linear bar and trough and rhythmic bar and beach states can develop during an accretionary sequence following antecedent dissipative beach states and associated wave conditions (Wright \& Short 1984, Wright et al. 1986). These are often termed 'reset' events and support the premise that LBT morphology is a result of high energy (erosive) wave events (e.g. van Enckevort and Ruessink 2003, Ranasinghe et. al. 2004, Smit et. al. 2008). Furthermore, Black \& Mead (2007) contend that "the most prominent bar and trough will form when waves approach perpendicular to the coast" 
(Scarfe 2008). Further observations suggest that LBT states are restricted to tide ranges below $1.5 \mathrm{~m}$ (Wright et al. 1986). The Gold Coast wave climate is such that oblique wave incidence events (particularly south to south east) are common and can exhibit the full range of wave heights experienced. This combined with the prevalence of LBT beach state occurrences outside of the mechanisms listed above suggests that an alternative mechanism also has the capacity to produce LBT morphology at this site. The potential for significant longshore currents and the absence of topographical features nearby (e.g. headlands, islands and reefs), results in an effectively long, straight beach. This topology combined with the prevalence of relatively short period, obliquely incident swell which does not undergo complete refraction en-route to the surf zone suggests the existence of an alternative bar-straightening mechanism which can result in transitions to LBT profiles on this coast.

Transitions to long-shore bar and trough beach states have been observed in response to a shift to oblique swell direction on the Northern Gold coast beaches. This is not limited to antecedent high energy dissipative conditions (such as a 'reset' event) but can occur for a wide range of wave heights. It is also noted that transitions to TBR morphology on the northern Gold Coast beaches can occur in response to a change to shore normal wave incidence during both increasing and decreasing swell events. The next section deals with the application of a numerical process-based model to lend further support to these observations.

\section{Wave Modelling Results}

The regional wave model (SWAN) was forced at the offshore boundary with significant wave height, peak period and direction from Wavewatch III global wave model hind casts (NOAA/NCEP). The nearest grid point to the study site was approximately $31 \mathrm{~km}$ offshore $\left(-28^{\circ} \mathrm{S}, 153.75^{\circ} \mathrm{E}\right)$. The wave spectrum assumes a JONSWAP shape with the default peak enhancement factor of 3.3. Battjes and Janssen (1978) depth induced breaking was applied with gamma equal to 0.73 . Nonlinear triad interactions were included with default values (alpha 0.1, beta 2.2). JONSWAP bottom friction was applied with a coefficient of 0.067 as the wave climate is typically short period swells.

Figure 13 displays the 3 hourly input and resulting significant wave height for the period from 7 th February to 10th July 2008. Significant wave height from the Gold Coast Seaway wave rider located at a depth of $16 \mathrm{~m}$ and at a distance of $1.2 \mathrm{~km}$ offshore from the study site is also displayed in Figure 13 . The general topography of the coastline is that of a prominent southern headland to the south and an embayment with an almost straight section of coastline in the study area (Figure 1). The wave model provides a good representation of the wave heights measured at the buoy. In particular there are several episodes of high offshore wave heights from a southerly direction which are strongly attenuated at the buoy location due to sheltering by the headland, island and reefs in the south of the region.

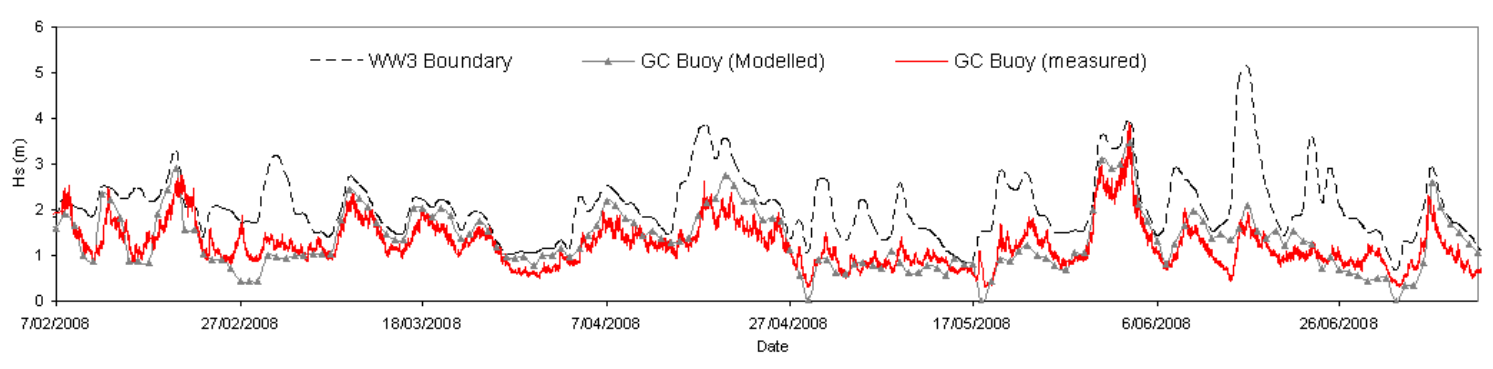

Figure 13. WW3 significant wave height model input, model output and Gold Coast buoy.

\section{Hydrodynamic model}

Nested within the regional wave model were successive nested grids. The highest resolution wave grid was constructed with a minimum cell size of $13.33 \mathrm{~m}$. This grid consisted of $74 \times 477$ grid cells resulting in a 
model domain of $0.986 \mathrm{~km}(\mathrm{X})$ by $6.358 \mathrm{~km}(\mathrm{Y})$. A separate computational flow grid was constructed to fit within the detailed wave grid. The computed radiation stress gradients and wave field information from SWAN is used as input for the FLOW module. Wind growth, white-capping and quadruplets were deactivated, propagation including refraction and frequency shifting were activated.

A morphological scale factor of 10 was set to scale up the morphological response by a factor of 10 for each time step. Since the output is stored after 60 minutes of run time each hour output image thus represents 10 hours of morphological evolution. Initial model runs were scheduled for 48 hours however this was reduced to 12 hours as the emergence of morphological features was satisfactory after only a few hours for each simulation.

Since the wave driven hydrodynamics were expected to dominate the emergence of features a static water level was set for the offshore boundary. Neumann boundary conditions are imposed at the lateral boundaries (north and south), this condition imposes a fixed zero alongshore water level gradient in the cross-shore direction at these boundaries (Roelvink \& Walstra 2004).

The modelled surf zone bathymetry represents a simplified case based on actual survey data. The wave conditions are parameterised and do not represent the full spectrum. No actual bathymetric data was available for calibration of the model output. These limitations therefore only permit a qualitative assessment of the impact of the model calibration factors on the model's ability to reproduce observed features of bar morphology in the subject area.

The depth-averaged sediment transport formulation of Bijker (1971) was adopted as it has produced realistic results for sediment transport due to interactions of currents and waves (DHL 2007). The experimental testing of model sensitivity to varying model parameters and input guided the selection of the most suitable parameters to apply to the simulation of beach state transition modelling. A time series of incident significant wave height, peak period and direction for the January 11th to January 15th, 2005 beach state transition (Figures 2 and 3) was then applied at the offshore boundary of the model.

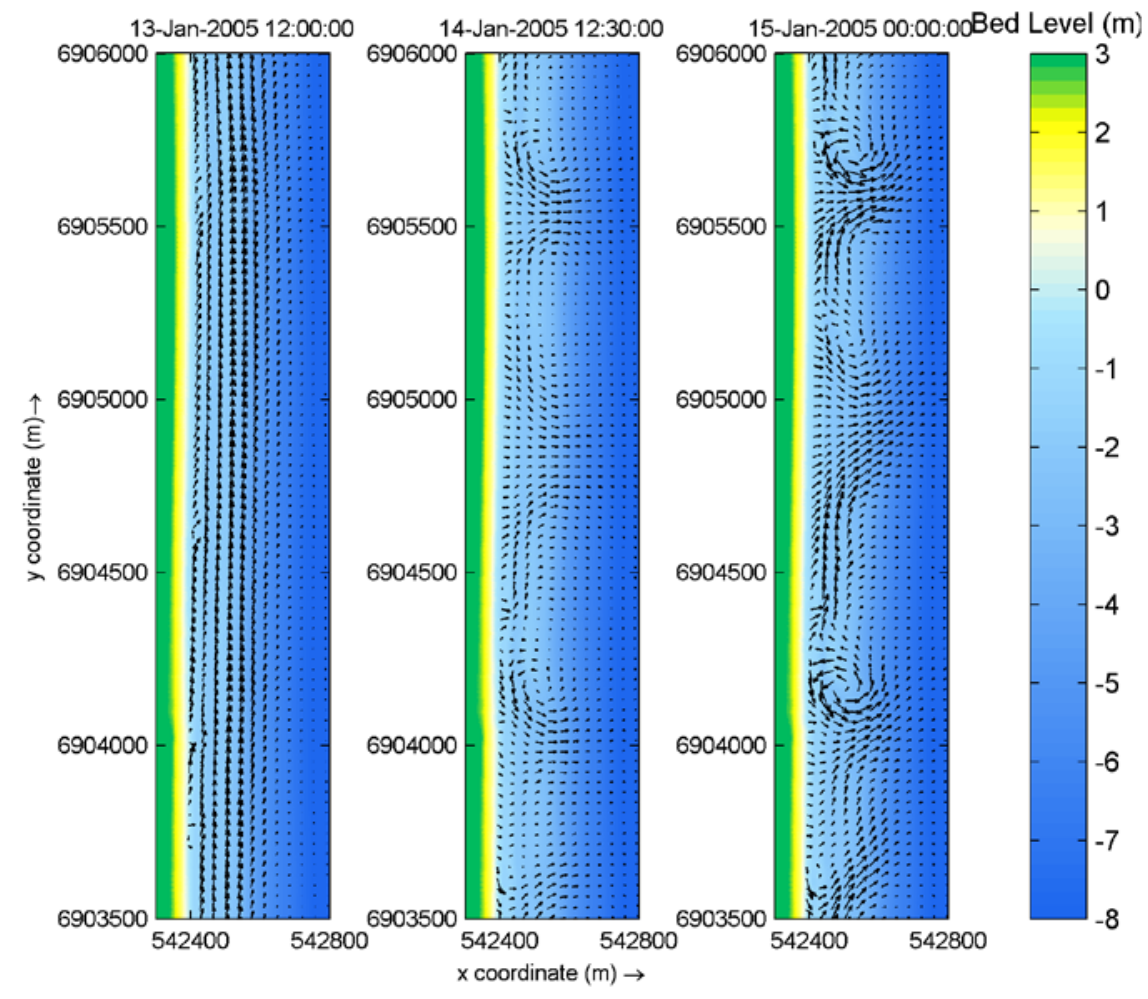

Figure 14. Model evolution of beach morphology and hydrodynamics with time series wave forcing. 
Paper No.

The initial beach state consisted of the idealised long shore uniform bar morphology. For the period up until January 13th, 2005, model bathymetry initially remained longshore uniform. This coincided with the period of obliquely incident (southerly) wave direction (Figure 6) and northward longshore transport. A shift to an easterly wave direction on January 14th, 2005 leads to the appearance of offshore directed flows in the model output. By January 15th rip cell circulation is well established and the morphology may now be exerting topographical control on the near shore circulation (Figure 14). This morphology prevailed for several days with very little change in the number and spacing of rips following the change in wave forcing.

The final model bathymetry representing the transverse bar and rip morphology of January 15th, 2005 was subsequently used to initialise a model whereby a shift in wave direction from shore normal incidence (east) to oblique incidence (south) occurred. A time series of significant wave height, peak period and direction was obtained for the period of February 5th to February 8th 2007. During this period significant wave height eased from $1.5 \mathrm{~m}$ to $1.2 \mathrm{~m}$, wave period varied between $7-8 \mathrm{~s}$ and incident wave direction shifted progressively from 93 degrees to 126 degrees (from east to southeast).

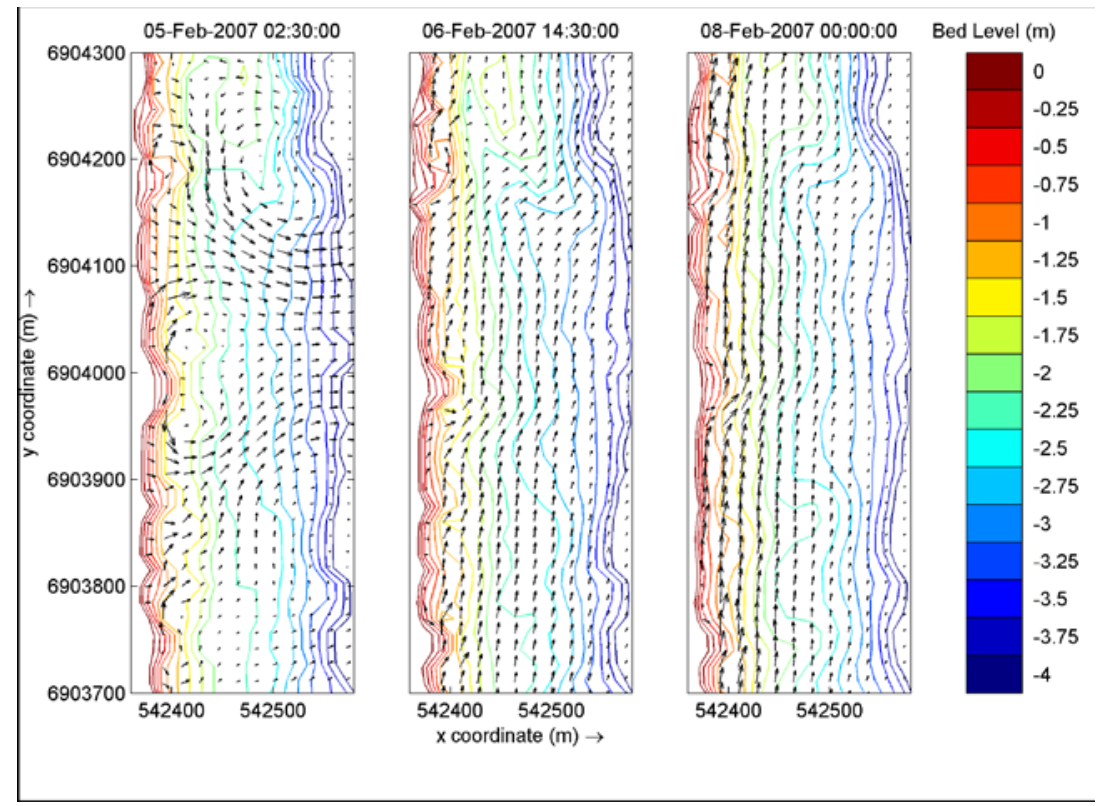

Figure 15. February 5th to 8th 2007 beach state evolution.

Figure 15 shows detail of the depth contours after 2.5 hours (left panel), 26.5 hours (middle panel) and 96 hours (right panel). The two rips prevailing in the first image tend to skew to the north with the shift in direction of wave incidence and then progressively migrate northwards. There is a corresponding reduction in alongshore non-uniformity of the morphology. The rip cell circulation is replaced by a longshore current however some offshore directed flow is still evident near the shoreline at less than $1 \mathrm{~m}$ depth. Note that the wave climate for this period is characterised by decreasing low energy swell and as such this transition is not considered to be typical of a 'reset' event as defined by previous literature.

\section{Conclusions}

Distinct surf zone bar morphologies have been described for a beach of the northern Gold Coast. The Wright and Short (1984) classification scheme was applied to differentiate between the morphological features representative of the intermediate beach states of longshore bar and trough and transverse bar and rip. Transitions between these beach states were identified from sequential time averaged video images. 
Paper No.

The prevailing wave climate prior to, during and following the transition between beach states was described using parameterised wave data from wave buoys and deep water wave model hindcast data. Clear mechanisms were proposed to be responsible for forcing the transitions and a numerical physical process model was tested for its ability to reproduce the identified beach state transitions.

A regional wave model was created with bathymetric data to a depth of $100 \mathrm{~m}$, representing the approximate location of the continental shelf edge. Sensitivity testing of several model parameters was conducted to determine appropriate settings for wave propagation to the near-shore nested hydrodynamic model. Modelling wave propagation using Wavewatch III hindcast deep-water boundary conditions with SWAN produced good agreement with measured near shore wave height data.

It was first hypothesized that an initially longshore uniform (long shore bar and trough) morphology could transform into a transverse bar and rip morphology in response to a shift in wave direction from obliquely incident to shore normally incident. A 2DH hydrodynamic and sediment transport model with initial longshore bar and trough morphology was forced with the conditions of an observed scenario corresponding to a change in wave direction from oblique to shore normal incidence. The numerical modelling was able to reproduce this morphodynamic sequence for state changes with timescales of the order of three days to a week. The resulting bathymetry containing rip channels was used as an initial condition to simulate a morphodynamic sequence of bar straightening.

The hypothesis derived from observations of timex images and analysis of wave conditions is that a transverse bar and rip morphology can tend towards a longshore uniform morphology under the action of obliquely incident wave conditions. The establishment of a longshore current induced by gradients in the radiation stress of obliquely approaching waves increases the longshore transport and tends to smooth out antecedent rip channel morphology.

This process was modelled for a low energy wave condition, demonstrating that a high energy swell event is not necessarily the only requisite condition for the appearance of a longshore bar and trough morphology. In the case modelled here however there was only a low relief bar/trough formed. The almost linear profile tended towards longshore uniform and the dissipation at the breakpoint could be expected to appear to be longshore uniform, particularly in time-averaged images. Under the action of increasing wave heights offshore bar migration is commonly observed however this process was not further investigated in study.

\section{Acknowledgements}

Data used in this study was obtained with the assistance of the Australian Environmental Protection Agency's Coastal Services Division, Australian Bureau of Meteorology, USA National Weather Service's National Centers for Environmental Prediction (NWS, NCEP, NOAA).

ARGUS images used were made available through the Water Research Laboratory of the University of New South Wales in conjunction with the Gold Coast City Council Environmental Monitoring Program and the Northern Gold Coast Beach Protection Strategy (NGCBPS).

This research was supported under the Australian Research Council's Discovery Projects funding scheme and Growing the Smart State PhD Funding Program.

\section{References}

Allen M.A. and Callaghan J., 2000. Extreme wave conditions for the South East Queensland coastal region, Environment Technical Report 32, Environmental Protection Agency, Brisbane.

Battjes, J.A. and Janssen, J., 1978. Energy loss and set-up due to breaking in random waves. Proceedings of the 16th International Conference on Coastal Engineering. Hamburg, 569-587.

Bijker, E.W., 1971. Longshore transport computations, Journal of the Waterways, Harbors and Coastal Engineering Division 97 (4), 687-701. 
Paper No.

Black, K. P. and Mead, S., 2007. Sand bank responses to a multi-purpose reef on an exposed sandy coast., Shore protection and surfing dedicated issue: Shore and Beach 75(4), 55-66.

Booij, N., Ris, R.C. and Holtjhuijsen, L.H., 1999. A third-generation wave model for coastal regions, part I: model description and validation. Journal of Geophysical Research, 104 (C4), 7649-7666.

DHL 2007. Delft 3d flow user manual, Technical report, Delft Hydraulics.

Ranasinghe, R., Symonds, G., Black, K. and Holman, R., 2004. Morphodynamics of intermediate beaches: a video imaging and numerical modelling study. Coastal Engineering, 51, 629-655.

Roelvink, J. A. and Walstra, D. J. R., 2004. Keeping it simple by using complex models. In Proceedings of the 6th International Conference on Hydroscience and Engineering, ICHE 2004, Brisbane, Australia.

Scarfe, B. ,2008. Oceanographic Considerations for the Management and Protection of Surfing Breaks. PhD thesis, Earth and Ocean Sciences, University of Waikato, New Zealand.

Smit, M. W. J., Reniers, A. J. H. M., Ruessink, B. G. and Roelvink, J. A. 2008. The morphological response of a nearshore double sandbar system to constant wave forcing. Coastal Engineering 55, 761770.

Surf Life Saving Australia. 2006. National Surf Safety Report 2006, Surf Life Saving Australia.

Tolman, H.L., 2002. User manual and system documentation of WAVEWATCH-III version 2.22. NOAA/NWS/NCEP/MMAB.

Turner, I., Leyden, V., Symonds, G., McGrath, J., Jackson, L., Jancar, T., Aarninkhof, S. and Elshoff, I. 2000. Comparison of observed and predicted coastline changes at the gold coast artificial (surfing) reef. In Proceedings of the 27th International Conference on Coastal Engineering, Sydney, Australia.

Turner, I.L., 2006. Discriminating Modes of Shoreline Response to Offshore-Detached Structures. Journal of Waterway, Port, Coastal and Ocean Engineering, 132(3), 180-191.

Strauss, D., Tomlinson, R. and Hunt, S. 2009. Profile response and dispersion of beach nourishment: Gold Coast, Australia. Journal of Coastal Research, SI 56 (Proceedings of the 10th International Coastal Symposium). Lisbon, Portugal.

van Enckevort, I. M. J. and Ruessink, B. G. 2003, Video observations of nearshore bar behaviour. Part 2: Alongshore non-uniform variability. Continental Shelf Research 23, 513-532.

Walsh, A., Tomlinson, R., McGrath, J., Boak, E. and Jackson, A. 1999. Environmental monitoring of the Northern Gold Coast Beach Protection Strategy. In Proceedings of Coasts and Ports 99, 14th Australasian Coastal and Ocean Engineering Conference and the 7th Australasian Port and Harbour Conference, Perth, Australia.

Wright, L.D., and Short, A.D. 1984. Morphodynamic variability of surf zones and beaches: A Synthesis. Marine Geology, 56, 93-118.

Wright, L. D., Nielsen, P., Shi, N. C. and List, J. H. 1986. Morphodynamics of a bar-trough surf zone. Marine Geology, 70, 251-285. 